\title{
Efficacy of antiparasitic drugs in control of gastrointestinal helminthiasis in naturally colored and white lambs from southern Brazil
}

\author{
[Eficácia de fármacos antiparasitários no controle de helmintos gastrointestinais em cordeiros \\ brancos e naturalmente coloridos do Sul do Brasil]
}

"Short Communication/Comunicação Breve"

\author{
Pablo Tavares Costa ${ }^{1^{*}}$, Rômulo Tavares Costa ${ }^{1}$, Alexsandro Bahr Kröning1, \\ Tiago Albandes Fernandes ${ }^{1}$, Ricardo Zambarda Vaz ${ }^{1}$, Sara Patron da Motta ${ }^{2}$, \\ Gilson de Mendonça ${ }^{3}$, Pâmela Peres Farias ${ }^{1}$
}

\begin{abstract}
${ }^{1}$ Departamento de Zootecnia, Universidade Federal de Pelotas (UFPel), Capão do Leão-RS, Brasil. ${ }^{2}$ Departamento do Instituto de Biologia, Universidade Federal de Pelotas (UFPel), Capão do Leão-RS, Brasil. ${ }^{3}$ Departamento de Fisiologia, Universidade Federal de Pelotas (UFPel), Capão do Leão-RS, Brasil.

*Autor para correspondência/Corresponding author: E-mail: pablocostta@hotmail.com
\end{abstract}

\begin{abstract}
Parasitic infections and the efficiency of different drugs were evaluated considering efficacy percentages, reduction in count of eggs per gram of feces (EPG) and larval culture in 60, 30 white and 30 naturally colored Corriedale lambs. Each phenotypic group was subdivided into six groups of five animals, each of which was administered one of the active ingredients: albendazole, levamisole hydrochloride, dysophenol, nitroxynil and moxidectin, in addition to a control group, unmedicated. Helminths were considered susceptible to nitroxinil and resistant to albendazole, levamisole, moxidectin (moderately effective) and to dysophenol (insufficiently active). In the culture of larvae, levamisole, nitroxinil and moxidectin were totally efficient $(100 \%)$ against Oesophagostomum spp., moxidectin was totally efficient against Trichostrongylus spp. and nitroxinil was efficient (97\%) against Haemonchus spp. Evaluating the EPG means of the phenotypic groups, it was observed higher parasitic infections in white ewes $(\mathrm{p}<0.05)$, in pre- and post-treatment. Therefore, it was concluded that the drug nitroxinil was the only effective for the reduction of the total parasite load of both phenotypic groups, being indicated for use in the herd in question. The genus Haemonchus spp. was the most prevalent and resistant to the drug action. Naturally colored Corriedale lambs, from the herd, showed increased resistance to gastrointestinal nematode infections.
\end{abstract}

Keywords: efficacy; antiparasitic; drug; helminth; sheep.

\section{Resumo}

Infecções parasitárias e a eficiência de diferentes fármacos foram avaliadas considerando-se percentuais de eficácia, redução na contagem de ovos por grama de fezes (OPG) e cultura de larvas, em 60 cordeiras da raça Corriedale, 30 brancas e 30 naturalmente coloridas. Cada grupo fenotípico foi subdividido em seis grupos de cinco animais, sendo administrado a cada um deles um dos princípios ativos: albendazol, cloridrato de levamisol, disofenol, nitroxinil e moxidectina, além de um grupo controle, não medicado. Os helmintos foram considerados susceptíveis ao nitroxinil e resistentes ao albendazol, levamisol, moxidectina (moderadamente efetivos) e ao disofenol (insuficientemente ativo). No cultivo de larvas, levamisol, nitroxinil e moxidectina foram totalmente eficientes (100\%) contra Oesophagostomum spp., moxidectina foi totalmente eficiente contra Trichostrongylus spp. e nitroxinil foi eficiente (97\%) contra Haemonchus spp. Avaliando as médias gerais de OPG, observou-se maiores infecções parasitárias nas cordeiras brancas $(\mathrm{p}<0,05)$, no pré e no pós-tratamento. Conclui-se que o fármaco nitroxinil foi o único eficiente para a redução da carga parasitária total de ambos os grupos fenotípicos, sendo indicado para utilização no rebanho em questão. O gênero Haemonchus spp. foi o mais prevalente e resistente à ação dos fármacos. Cordeiras Corriedale naturalmente coloridas, do rebanho utilizado, apresentam maior resistência à infestação por nematoides gastrintestinais.

Palavras-chave: eficácia; antiparasitário; medicamento; helminto; ovinos. 
Gastrointestinal (GI) parasitic infections are one of the major health problems affecting sheep herds worldwide (Taylor et al., 2007; Molento et al., 2013; Vieira et al., 2014) and can reduce the productivity of herds and result in high mortality rates if treatment, prevention and control measures are not readily implemented (Vieira et al., 2014; Benavides et al., 2015; Silva et al., 2017). Young animals are particularly susceptible to GI nematode infections as they are unable to mount an effective immune response against these parasites (Schallig, 2000).

The administration of anthelmintics is widely used for the control of parasitic infections including nematode infections (Amarante and Sales, 2007). However, prolonged use of antihelminthics results in antiparasitic drug resistance. There are reports of resistance of parasites to the main antiparasitic drugs available in the market for the treatment of gastrointestinal helminthiases of farm animals (Taylor et al., 2007; Cezar et al., 2010; Nova et al., 2014; Vieira et al., 2014; Dias et al., 2015; Costa et al., 2017; Silva et al., 2017).

Sheep farming relies heavily on anthelmintics for the control of parasitic infections. Therapeutic and prophylactic use of anthelmintics in livestock represent a potential risk for food safety as residues of veterinary drugs can persist in animal products intended for human consumption. (Cerqueira et al., 2014). Therefore, other possibilities for the treatment and control of parasitic diseases in livestock should be pursued. Sheep breeding for resistance against gastrointestinal nematodes would be one of the alternative strategies to circumvent drug resistance (Woolaston et al., 1996; Vieira et al., 2014).

Natural colored sheep are considered more rustic animals and are naturally resistant to a number of diseases that affect ovine herds globally including gastrointestinal helminthiases (Saueressig, 2015). However, few studies have investigated the influence of the color of the skin and wool of sheep on the health status of these animals.

The present study aimed to assess the efficacy of $10 \%$ albendazole, $18.8 \%$ levamisole hydrochloride, $10 \%$ disophenol, $34 \%$ nitroxynil, and $1 \%$ moxidectin in the treatment of nematode infections in Corriedale white lambs and naturally colored lambs from a flock of sheep from Southern Brazil naturally infected with different species of gastrointestinal nematodes. The following parameters were considered in this assessment: drug efficacy, reduction of the number of eggs per gram of feces (EPG) in fecal egg counts before treatment and after treatment, and larval cultures (coproculture).

Data collection was done in July 2017 during a visit to a farm located in the city of Pinheiro Machado, RS, Brazil, between 31 31'30" South Latitude and 53 29'45" West Longitude in a rural area that belongs to the Pampa Biome.

In this study were used 60 Corriedale lambs from 2 phenotypic groups (30 white lambs and 30 naturally colored lambs) with 8-9 months of age and mean body weight of $30.15 \pm 1.91 \mathrm{~kg}$. Criteria for selecting animals for this research were that they were not treated with any anthelmintic drug for at least 80 days before beginning the study, and only animals that had Famacha scores between 3 and 5 according to the methods published by Molento et al. (2013) were included in this study. Lambs were identified with numbered ear tags and kept in an extensive grazing system with native pastures as the major food source and plenty of water and natural shade.

Animals were randomly divided into 6 groups of 10 lambs each (5 white lambs and 5 naturally colored lambs) and were subjected to the following treatments: albendazole $10 \%$ administered orally at a dosage of $1 \mathrm{~mL} / 10 \mathrm{~kg}$ body weight; levamisole hydrochloride $18.8 \%$ applied subcutaneously at a dosage of $1 \mathrm{~mL} / 40 \mathrm{~kg}$ body weight; disophenol $8 \%$ administered orally at a dosage of $1 \mathrm{~mL} / 10 \mathrm{~kg}$ body weight; nitroxynil $34 \%$ injected subcutaneously at a dosage of $1 \mathrm{~mL} / 30 \mathrm{~kg}$ body weight; and moxidectin $1 \%$, applied subcutaneously at a dosage of $1 \mathrm{~mL} / 50 \mathrm{~kg}$ body weight. Animals from the control group were not treated with any antiparasitic drug during the study. The dosage and route of administration were chosen according to the manufacturers' recommendations. Each animal was weighed on an electronic digital scale after a 12-hour fasting.

Fecal egg counts were performed pre- and post-treatment (day 0 before treatment and day 7 after treatment) in order to assess fecal egg shedding rates and drug efficacy. The fecal egg counting technique published by Gordon and Whitlock in 1939 was used in this study. Fecal samples were collected from the rectum after manual stimulation of the perianal and rectal regions (fecal grab sampling). Feces were placed in labeled plastic bags and stored under refrigeration for the egg counts were performed up to 16 hours after collected. 
Arithmetic means of eggs per gram (EPG) were determined both pre-and posttreatment. Percentages of EPG reduction and drug efficacy were calculated based on the averages (Wood et al., 1995). To calculate the EPG percentage reduction, results of the fecal egg counts from each group pretreatment and 7 days post-treatment were compared according to the equation Reduction (\%) $=[100($ EPG average day $0-$ EPG average day 7) $]$ / EPG average of day 0.

The following formula was used to calculate the efficacy of each treatment regimen: Efficacy $(\%)=[100($ mean EPG of the control group - mean EPG of the treated group)]/mean EPG of the control group.

Ordinance 48/1997 MAPA (Brazilian Ministry of Agriculture, Livestock and Food Supply) for antiparasitic substances was used as a reference in our assessment of drug efficacy in the treatment of sheep infected with gastrointestinal helminths. According to the criteria established by this regulation, an antiparasitic drug is considered highly effective when treatment reduces over $98 \%$ of the parasite load, effective when it reduces between 90 and $98 \%$ of the parasite load, moderately effective when it reduces between 80 to $89 \%$ of the parasite load, and insufficiently active when it reduces less than $80 \%$ of the parasite load (BRASIL, 1997).

Fecal culture was performed according to the method described by Roberts and O'Sullivan (1950) in order to identify gastrointestinal nematode larvae in fecal samples from these animals in the pre- and post-treatment periods. For this, the identification was made of 100 larvae randomly selected in the optical microscopy examination. In samples with less than 100 larvae, all were identified and quantified, and the proportion established. Fecal egg counts and fecal culture were conducted at the UFPel Department of Animal Science and Department of Parasitology, respectively.

Reso Fecrt ${ }^{\circledR}$ software version 4.0 (http://www.vetsci.usyd.edu.au/sheepwormcontrol) was used to assess the levels of anthelmintic resistance of different nematode genera to several drugs tested in each phenotypic study groups (white lamb group and naturally-colored lamb group). The percentages of gastrointestinal larvae of each nematode genus recovered from feces in the pre(Day 0) and post-treatment (Day 7) periods were compared. Anthelmintics were considered effective if they were capable of reducing at least $95 \%$ of the parasite loads considering each individual genus or in combination with other genera and species of nematodes (Coles et al., 1992).

A completely randomized design that was replicated 5 times was performed in a $2 \times 6$ factorial arrangement with 2 phenotypic groups composed of white lambs and naturally colored lambs, 5 antiparasitic drugs (albendazole, levamisole hydrochloride, disophenol, nitroxynil, and moxidectin), 1 control non-treated group. Fecal egg count data was submitted to analysis of variance and, when significant, the means of the treatments were compared by least-squares means (LSMEANS Statement) of the SAS ${ }^{\circledR}$ program (Statistical Analysis System), version 9.0 for Windows ${ }^{\circledR}$, adopting a 5\% significance level. The means of the phenotypic groups were compared to each other by Student's t-test adopting a 5\% significance level.

Mean fecal egg counts were quite high in the pre-treatment period (Table 1). In both phenotypic groups, fecal egg counts were reduced after anthelmintic administration and fecal egg counts were elevated in the control, non-treated animals $(\mathrm{p}<0.05)$.

Nitroxynil was the most effective antiparasitic drug ad significantly reduced fecal egg counts in both phenotypic groups and was the only anthelmintic that could be categorized as effective according to the evaluation criteria established by MAPA (BRASIL, 1997). Recent studies showed that nitroxynil is efficient against gastrointestinal nematodes of ruminants (Nova et al., 2014; Costa et al., 2017).

Nitroxynil (34\% w/v solution) is not recommended for the control of Trichostrongylus spp. infections in sheep and goats but it is indicated for the control of Haemonchus infections in small ruminants (Van Wyk et al., 1999). Despite the fact that nitroxynil $34 \%$ didn't perform well in the treatment of Trichostrongylus spp. infections, this antiparasitic drug was able to clear Haemonchus spp. infections almost completely (reduction of $97 \%$ in parasite load) and was highly effective against Oesophagostomum spp. infections (100\% reduction in parasite load) (Table 2).

Resistant parasites to $10 \%$ albendazole, $18.8 \%$ levamisole hydrochloride and $1 \%$ moxidectin were detected in our study. These antiparasitic drugs were considered moderately effective against gastrointestinal worms according to MAPA criteria (BRASIL, 1997) as there was only partial reduction of parasite loads in both 
phenotypic groups after treatment with these anthelmintics (Table 1). These active ingredients represent the three major classes of broad-spectrum drugs used to control gastrointestinal nematodes in farm animals around the world (Mckellar and Jackson, 2004; Wolstenholme et al., 2004).

Table 1. Mean and standard deviation of EPG (eggs per gram of feces) numbers, percentage of efficacy, and percentage of reduction of EPG numbers prior to and after treatment of white lambs and natural colored Corriedale lambs with various anthelmintics against gastrointestinal nematodes.

\begin{tabular}{ccccc}
\hline & \multicolumn{3}{c}{ White Lambs } \\
\cline { 2 - 3 } Anthelmintic & Day 0 & Efficiency \% & Reduction \% \\
\cline { 2 - 3 } & $2360 \pm 2834$ & $1160 \pm 1883$ & 86,27 & 50,84 \\
\hline Levamisole & $3940 \pm 2048$ & $1540 \pm 1382$ & 81,77 & 60,51 \\
Albendazole & $9140 \pm 4920$ & $360 \pm 242$ & 95,74 & 96,06 \\
Nitroxinil & $5800 \pm 3815$ & $1240 \pm 882$ & 85,32 & 78,62 \\
Moxidectin & $6740 \pm 5213$ & $4020 \pm 3187$ & 52,42 & 40,36 \\
Disophenol & $4350 \pm 1698$ & $8450 \pm 2388$ & - & $-94,25$ \\
Control & $1300 \pm 390$ & $340 \pm 344$ & 88,96 & 73,85 \\
& $4140 \pm 4417$ & $1040 \pm 1280$ & 66,23 & 74,88 \\
Levamisole & $2075 \pm 2440$ & $250 \pm 195$ & 91,88 & 87,95 \\
Albendazole & $5720 \pm 5008$ & $1360 \pm 2060$ & 55,84 & 76,22 \\
Nitroxinil & $2160 \pm 2485$ & $1800 \pm 2059$ & 41,56 & 16,67 \\
Moxidectin & $1350 \pm 161$ & $3080 \pm 722$ & - & $-128,15$ \\
Disophenol & & & & \\
Control & & &
\end{tabular}

A number of published surveys on the prevalence of anthelmintic resistance in sheeps in the State of Rio Grande do Sul (RS), Southern region of Brazil shows that this is a serious problem, since the early 90s, benzimidazole resistance was present in approximately $90 \%$ of the herds, and levamisole resistance was detected in $84 \%$ of farm animals (Echevarria et al., 1996). More recently, studies conducted in this same Brazilian State showed that albendazole and levamisole were not efficient in the treatment of gastrointestinal worms of livestock (Cezar et al., 2010; Dias et al., 2015; Costa et al., 2017).

In the present study, moxidectin was moderately efficient against gastrointestinal helminths in white lambs $(85.32 \%)$ and was found to be inefficient against nematode infections of the GI tract in natural-colored lambs (55.84\%). There have been numerous reports on parasite resistance to macrocyclic lactones published in Brazil and elsewhere (Veríssimo et al., 2012) with an efficacy close to $80 \%$ (Costa et al., 2017). In this study, moxidectin was able to entirely clear Oesophagostomum spp. and Trichostrongylus spp. infections in both phenotypic groups with $100 \%$ reduction of parasite loads (Table 2). Therefore, moxidectin would be a drug of choice in the treatment of GI nematode infections in sheep.

Disophenol was the least efficient antiparasitic drug since there was not any significant reduction in fecal egg counts after treatment. According to the guidelines provided by MAPA (BRASIL, 1997) and based on our findings, this drug would be considered insufficiently active in the two parasitized phenotypic groups studied and therefore should not be used in the treatment of gastrointestinal nematode infections in sheep. Disophenol resistance in lambs from the State of Rio Grande do Sul, southern Brazil, was recently documented by Silva et al. (2017). Similar findings were reported by Cezar et al. (2010) even when the drug was used at higher concentrations (20\% disophenol).

There was marked increase in the fecal egg counts from the control, non-medicated group, possibly due to the animals being kept in the same environment, in which, due to the pre-treatment results, it is estimated that it had a high concentration of parasite larvae. Higher parasitic loads were found in white lambs that were not treated $(\mathrm{p}<0.05$ - Table 3$)$.

Haemonchus spp. was the most prevalent nematode in pre- and post-treatment coprocultures. These findings corroborate those of previous research done by Amarante and Sales (2007) and Benavides et al. (2015). Haemonchus spp. is the most prevalent helminth in tropical and subtropical regions of the world especially during the summer and autumn and is highly pathogenic to lambs. This prevalence can be demonstrated in our herd by preselection of animals using the Famacha method to assess anemia and detect haemonchosis in small 
ruminants (Van Wyk et al., 1999). Other factors that may have contributed to the large number of cases of haemonchosis was the high temperatures and high rainfall index.

In the present study, the efficacy of both albendazole and nitroxynil as antiparasitic drugs against each nematode genus could not be assessed in natural colored lambs since fecal culture yielded negative results (Table 2).

General averages of fecal egg counts from each phenotypic group during the pretreatment period showed higher parasite loads and more severe nematode infections in white lambs $(\mathrm{p}<0.05$ - Table 4) with values of 5,475.5 EPG for white lambs and 2,910.5 EPG for natural colored animals. A similar pattern was observed after the administration of the drugs (posttreatment period) with lower fecal egg counts in the naturally colored group ( $\mathrm{p}<0.05$ - Table 4$)$ with values of $2,280.9$ EPG and 1,127.9 EPG in white lambs and natural colored lambs, respectively.

Table 2. Efficacy (EF) of various anthelmintics against each genus of gastrointestinal nematode infecting white lambs and natural colored Corriedale lambs.

\begin{tabular}{cccccccccc}
\hline \multicolumn{10}{c}{ White Lambs } \\
\hline \multirow{2}{*}{ Anthelmintic } & \multicolumn{1}{c}{ Haemonchus $(\%)$} & \multicolumn{1}{c}{ Trichostrongylus $(\%)$} & \multicolumn{3}{c}{ Oesophagostomum $(\%)$} \\
\cline { 2 - 10 } & Day 0 & Day 7 & EF & Dia 0 & Dia 7 & EF & Dia 0 & Dia 7 & EF \\
\hline Levamisole & 82 & 90 & 81 & 12 & 10 & 95 & 6 & 0 & 100 \\
Albendazole & 63 & - & - & 25 & - & - & 12 & - & - \\
Nitroxynil & 62 & 42 & 97 & 31 & 58 & 91 & 6 & 0 & 100 \\
Moxidectin & 81 & 100 & 78 & 13 & 0 & 100 & 6 & 0 & 100 \\
Disophenol & 62 & 50 & 64 & 25 & 34 & 40 & 13 & 16 & 0 \\
Control & 57 & 66 & - & 37 & 27 & - & 6 & 6 & - \\
\hline & & & Natural Colored Lambs & & & & \\
\hline Levamisole & 82 & 88 & 88 & 12 & 12 & 83 & 6 & 0 & 100 \\
Albendazole & 63 & - & - & 25 & - & - & 12 & - & - \\
Nitroxynil & 62 & - & - & 31 & - & - & 6 & - & - \\
Moxidectin & 81 & 100 & 46 & 13 & 0 & 100 & 6 & 0 & 100 \\
Disophenol & 62 & 50 & 88 & 25 & 33 & 0 & 13 & 17 & 6 \\
Control & 77 & 82 & - & 9 & 8 & - & 16 & 10 & - \\
\hline
\end{tabular}

*Efficacy was calculated using the software Reso Fecrt®, version 4.0.

Table 3. Mean and standard deviation of EPG (eggs per gram of feces) numbers post-treatment after dosing Corriedale white (WH) lambs and naturally colored (NC) lambs with various anthelmintics against gastrointestinal nematodes.

\begin{tabular}{lcc}
\hline \multicolumn{1}{c}{ Anthelmintic } & \multicolumn{2}{c}{ EPG Day 7 } \\
\cline { 2 - 3 } & White & Natural colored \\
\hline Levamisole & $1160 \pm 1883^{\mathrm{Aa}}$ & $340 \pm 344^{\mathrm{Aa}}$ \\
Albendazole & $1540 \pm 1382^{\mathrm{Aab}}$ & $1040 \pm 1280^{\mathrm{Aab}}$ \\
Nitroxynil & $360 \pm 242^{\mathrm{Aa}}$ & $250 \pm 195^{\mathrm{Aa}}$ \\
Moxidectin & $1240 \pm 882^{\mathrm{Aa}}$ & $1360 \pm 2060^{\mathrm{Aac}}$ \\
Disophenol & $4020 \pm 3187^{\mathrm{Ab}}$ & $1800 \pm 2059^{\mathrm{Aa}}$ \\
Control & $8450 \pm 2388^{\mathrm{Ac}}$ & $3080 \pm 722^{\mathrm{Bbd}}$ \\
\hline
\end{tabular}

*In this table, means are followed by uppercase letters in each row and averages followed by lowercase letters in each column are different from each other in the $t$ test $(\mathrm{P}<0,05)$.

Table 4. Mean and standard deviation of EPG (eggs per gram of feces) counts in Corriedale white lambs and natural colored lambs infected with gastrointestinal nematodes pre and post-treatment with various anthelmintics

\begin{tabular}{cccc}
\hline \multirow{2}{*}{ Treatment } & \multicolumn{3}{c}{ EPG } \\
\cline { 2 - 4 } & White & Natural colored & $\mathrm{P}$ \\
\hline Pre-treatment & $5475,5 \pm 4771,8^{\mathrm{b}}$ & $2910,5 \pm 4081,0^{\mathrm{a}}$ & 0,0208 \\
Post-treatment & $2280,9 \pm 2969,5^{\mathrm{b}}$ & $1127,9 \pm 1503,0^{\mathrm{a}}$ & 0,0480 \\
\hline
\end{tabular}

*Means are followed by letters in rows differ from each other the $t$ test $(\mathrm{P}<0,05)$.

These findings allow us to infer that natural colored sheep, used in the present study, are more resistant to parasitic infections than white ones. These results are in accordance with those of
Saueressig (2015) who found that even younger animals of this particular phenotype are more resistant to gastrointestinal helminthiases. 
In Brazil, selective breeding of sheep for white wool began several decades ago. At that time, naturally-colored sheep were not common in sheep production and marketing systems and, until the last decade, there were few breeding programs targeting this particular phenotype. In recent years, Brazilian farmers started selective breeding programs focusing on reproductive and meat traits of sheep. Research on genetic improvement in sheep has shown that achieving a balance between productivity and immunity against gastrointestinal nematodes is challenging (Greer, 2008). It is suggested that, since natural colored sheep have not participated in selective breeding programs prioritizing production traits, they possibly have a higher frequency of genes that make them more resilient to parasitic infections. In Brazil, there are around 31 different breeds of purebred sheep, and only 3 of them - Crioula, Morada Nova, and Santa Inês - are considered rustic (Amarante and Sales, 2007). A naturally colored fur or wool is a phenotypic trait that they have in common. Based on our findings and those from previous studies published by other researchers, we suggest that in sheep there is a correlation between wool pigmentation and innate resistance to parasites.

Additional studies are needed to confirm whether this feature is also present in other Corriedale sheep herds, categories and sheep breeds. Other aspects that should also be investigated include the presence of putative innate immunity-related genes that would increase resistance of natural colored sheep breeds to gastrointestinal nematodes.

Over the years, there has been an increase in antihelmintic resistance in farm animals. Therefore, alternatives for the treatment, control and prevention of gastrointestinal nematode infections should be pursued in order to tackle the problem of parasite drug resistance (Costa et al., 2017). The use of genetically resistant sheep (Molento et al., 2013) would be a possible option to reduce the costs and expenses with drugs, staff, and veterinary care, and would help in the implementation of adequate therapeutic, prophylactic and control measures.

Resistance to GI nematodes in sheep is a trait which estimated heritability lies between 0.3 and 0.5 (Amarante et al., 2004). Thus, the establishment of ovine genotypes associated with resistance to parasites would be an interesting tool in the prophylaxis of gastrointestinal helminthiases.
Based on our results, we conclude that nitroxynil $34 \%$ is the only drug that can effectively reduce parasite loads in both phenotypic groups and should be the drug of choice to treat gastrointestinal helminthiases in the ovine herd studied. Haemonchus spp. was the most prevalent nematode and the most resistant nematode to the antiparasitic drugs tested. Naturally colored Corriedale lambs, from the herd used, showed increased resistance to gastrointestinal nematode infections. Further studies are suggested to identify whether these results are repeated in other herds, races and categories of animals, as well as to check whether skin and wool coloration has an impact on resistance to parasitic infestation.

\section{Conflict of interests}

The authors declare that there is no conflict of interest.

\section{Ethics Committee}

This research project was approved by the Ethics Committee on Animal Use from the Federal University de Pelotas, located in the city of Pelotas, Brazil (research proposal no. 5821).

\section{Acknowledgment}

This study was financed in part by the Coordenação de Aperfeiçoamento de Pessoal de Nível Superior - Brazil (CAPES) - Finance Code 001.

\section{References}

Amarante, A.F.T.; Sales, R.O. Control of endoparasitoses of sheeps: a revision. Revista Brasileira de Higiene e Sanidade Animal, 1(2): 14-36, 2007.

Amarante, A.F.T.; Bricarello, P.A.; Rocha, R.A.; Gennari, S.M. Resistance of Santa Ines, Suffolk and Ile de France sheep to naturally acquired gastrointestinal nematode infections. Veterinary Parasitology, 120(1-2): 91-106, 2004.

Benavides, M.V.; Sonstegard, T.S.; Kemp, S.; Mugambi, J.M.; Gibson, J.P.; Baker, R.L.; Hanotte, O.; Marshall, K.; Tassell, C.V. Identification of novel loci associated with gastrointestinal parasite resistance in a Red Maasai x Dorper backcross population. PloS One, 10(4): 1-20, 2015.

BRASIL. Ministério da Agricultura, Pecuária e Abastecimento. Portaria no 48, de 15 de maio de 1997. In: Regulamento técnico para 
licenciamento e/ou renovação de licença de produtos antiparasitários de uso veterinário. Seção 1: 10165. Cited: 2017 Jul. 17.

Cerqueira, M.M.O.P.; Souza, F.N.; Cunha, A.F.; Picinin, L.C.A.; Leite, M.O.; Penna, C.F.A.M.; Souza, M.R.; Fonseca, L.M. Detection of antimicrobial and anthelmintic residues in bulk tank milk from four different mesoregions of Minas Gerais State - Brazil. Arquivos Brasileiros de Medicina Veterinária e Zootecnia, 66(2): 621-625, 2014.

Cezar, A.S.; Toscan, G.; Camillo, G.; Sangioni, L.A.; Ribas, H.O.; Vogel, F.S.F. Multiple resistance of gastrointestinal nematodes to nine different drugs in a sheep flock in southern Brazil. Veterinary Parasitology, 173(1-2): 157-160, 2010.

Coles, G.C.; Bauer, C.; Borgsteede, F.H.M.; Geerts, S.; Klei, T.R.; Taylor, M.A.; Waller, P.J. World Association for the Advancement of Veterinary Parasitology (WAAVP) methods for the detection of anthelmintic resistance in nematodes of veterinary importance. Veterinary Parasitology, 44(1-2): 35-44, 1992.

Costa, P.T.; Costa, R.T.; Mendonça, G.; Vaz, R.Z. Eficácia anti-helmíntica comparativa do nitroxinil, levamisol, closantel, moxidectina e fenbendazole no controle parasitário em ovinos. Boletim de Indústria Animal, 74(1): 72-78, 2017.

Dias, A.S.; Feleti, S.V.; Carmo, H.B.; Andrade, T.A.; Matos, E.R.; Kiefer, H.G.; Camporez, C.C. Comparação da eficácia de albendazol e a associação entre abamectina e levamisole em ovinos. Scientific Electronic Archives, 8(1): 25-28, 2015.

Echevarria, F.A.M.; Borba, M.F.S.; Pinheiro, A.C.; Waller, P.J.; Hansen, J.W. The prevalence of anthelmintic resistance in nematode parasites of sheep in Southern Latin America: Brazil. Veterinary Parasitology, 62(3-4): 199-206, 1996.

Gordon, H.McL.; Whitlock, H.V. A new technique for counting nematode eggs in sheep faeces. Journal of the Council for Scientific and Industrial Research, 12(1): 50-52, 1939.

Greer, A.W. Trade-offs and benefits: implications of promoting a strong immunity to gastrointestinal parasites in sheep. Parasite Immunology, 30(2): 123-132, 2008.

Molento, M.B.; Veríssimo, C.J.; Amarante, A.T.; Van Wyk, J.A.; Chagas, A.C.S.; Araújo, J.V.;
Borges, F.A. Alternativas para o controle de nematoides gastrintestinais de pequenos ruminantes. Arquivos do Instituto de Biologia, 80(2): 253-263, 2013.

Nova, L.E.V.; Costa, M.E.; Melo, P.G.C.F.; Cunha Filho, L.F.C.; Barca Júnior, F.A.; Silva, L.C.; Okano, W.; Bogado, A.L.G. Resistência de nematoides aos anti-helmínticos nitroxinil 34\% e ivermectina $1 \%$ em rebanho ovino no município de São João do Ivaí, Paraná. Revista Brasileira de Higiene e Sanidade Animal, 08(1): 160-171, 2014.

Roberts, F.H.S.; O'Sullivan, P.J. Methods for egg counts and larval cultures for strongyles infesting the gastro-intestinal tract of cattle. Australian Journal of Agricultural Research, 1(1): 99-102, 1950.

Saueressig, D. Ovinos/caprinos - mais diversidade. Revista A Granja, 191: 1-1, 2015.

Schallig, H.D. Immunological responses of sheep to Haemonchus contortus. Parasitology, 120(Suppl.): 63-72, 2000.

Silva, D.G.; Pilatti, J.A.; Menezes, B.M.; Brum, L.P.; Netto, C.G.; Martins, A.A. Eficácia anti-helmíntica comparativa entre diferentes princípios ativos em ovinos jovens. Pubvet, 11(4): 356-362, 2017.

Taylor, M.A.; Coop, R.L.; Wall, R.L. Veterinary parasitology. $3^{\text {rd }}$ ed. Oxford: Blackwell Publishing, 2007. 874 pp.

Van Wyk, J.A.; Stenson, M.O.; Van der Merwe, J.S.; Vorster, R.J.; Viljoen, P.G. Anthelmintic resistance in South Africa: surveys indicate an extremely serious situation in sheep and goat farming. The Onderstepoort Journal of Veterinary Research, 66(4): 273-284, 1999.

Veríssimo, C.J.; Niciura, S.C.M.; Alberti, A.L.L.; Rodrigues, C.F.C.; Barbosa, C.F.C.; Chiebao, D.P.; Cardoso, D.; da Silva, G.S.; Pereira, J.R.; Margatho, L.F.; da Costa, R.L.; Nardon, R.F.; Ueno, T.E.; Curci, V.C.; Molento, M.B. Multidrug and multispecies resistance in sheep flocks from São Paulo state, Brazil. Veterinary Parasitology, 187(1-2): 209-216, 2012.

Vieira, L.S.; Teixeira, M.; Minho, A.P.; Borba, M.F.S.; Vasconcelos, A.L.C.F.; Beviláqua, C.M.L. Doenças parasitárias de ovinos. In: Selaive, A.B.; Osório, J.C.S. Produção de ovinos no Brasil. São Paulo: Roca, 2014. p. 311-342.

Woolaston, R.R.; Piper, L.R. Selection of Merino sheep for resistance to Haemonchus contortus: genetic variation. Animal Science, 62(3): 451460, 1996. 
Wood, I.B.; Amaral, N.K.; Bairden, K.; Duncan, J.L.; Kassai, T.; Malone, J.B.; Pankavich, J.A.; Reinecke, R.K.; Slocombe, O.; Taylor, S.M. World Association for the Advancement of Veterinary Parasitology (W.A.A.V.P.) second edition of guidelines for evaluating the efficacy of anthelmintics in ruminants (bovine, ovine, caprine). Veterinary Parasitology, 58(3): 181$213,1995$. 